\title{
THE QUANTITATIVE DETERMINATION OF HYDROGEN PEROXIDE BY VOLTAMMETRY ON THE CARBOSITALL ELECTRODE
}

\author{
M.Blazheyevskiy, O.Mozgova \\ National University of Pharmacy \\ Key words: determination; hydrogen peroxide; voltammetry; carbositall rotation electrode; antiseptic \\ (skin disinfectant)
}

\begin{abstract}
The electrochemical behaviour of hydrogen peroxide $\left(\mathrm{H}_{2} \mathrm{O}_{2}\right)$ has been studied using the alternating current voltammetry with square wave modulation in the potential range of $+1.0 \ldots-1.0 \mathrm{~V}$ on the carbositall electrode as a working and auxiliary electrode (vs Ag, $\mathrm{AgCl} / \mathrm{KCl}(\mathrm{sat})$ ). The peak was obtained at $E_{p}=+0.16 \mathrm{~V}$ on the background of $0.1 \mathrm{Mol} \mathrm{L}^{-1} \mathrm{Na}_{2} \mathrm{SO}_{4}$ and $0.01 \mathrm{Mol} \mathrm{L}^{-1} \mathrm{KHSO}_{4}(\mathrm{pH} \approx 2.4)$ with its height rising proportionally to the increase of $\mathrm{H}_{2} \mathrm{O}_{2}$ concentrations. The linear dependence was observed in the $\mathrm{H}_{2} \mathrm{O}_{2}$ concentration range of $(1.7-10.2) \times 10^{-5} \mathrm{Mol} \mathrm{L}^{-1}$, the calibration curve equation was $I_{p}=(8.6 \pm 0.7) \times 10^{3} \mathrm{C}(r=0.998) ; L O D=6.16 \times 10^{-6} \mathrm{Mol} \mathrm{L}^{-1}, L O Q=2.05 \times 10^{-5} \mathrm{Mol}^{-1}$. To determine $\mathrm{H}_{2} \mathrm{O}_{2}$ in solutions of antiseptic drugs the standard addition method was used.
\end{abstract}

Hydrogen peroxide $\left(\mathrm{H}_{2} \mathrm{O}_{2}\right)$ is one of the most versatile oxidants, which oxidizing activity exceeds the known oxidizing agents - chlorine, chlorine dioxide and potassium permanganate; as a result of catalysis, $\mathrm{H}_{2} \mathrm{O}_{2}$ can be transformed into the hydroxyl radical $(\mathrm{OH} \bullet)$, which is the second after Fluorine by its reactivity. In addition to the oxidizing properties $\left(\mathrm{H}_{2} \mathrm{O}_{2}+2 \mathrm{H}^{+}+2 \mathrm{e}^{-} \rightarrow 2 \mathrm{H}_{2} \mathrm{O}, \mathrm{E}^{\mathrm{o}}=1.78 \mathrm{~V}\right)$ it can be used as a reducing agent $\left(\mathrm{H}_{2} \mathrm{O}_{2}+2 \mathrm{OH}^{-} \rightarrow \mathrm{O}_{2}+\right.$ $\left.2 \mathrm{H}_{2} \mathrm{O}+2 \mathrm{e}^{-}, \mathrm{E}^{\mathrm{o}}=-0.15 \mathrm{~V}\right)$ [22].

Thus, $\mathrm{H}_{2} \mathrm{O}_{2}$ is widely used in various industrial processes, such as the textile and paper industries for bleaching materials [20], and promotes controlled fibre swelling [22]. In the work [17] $\mathrm{H}_{2} \mathrm{O}_{2}$ was used to enhance the oxidizing potential in remediation of soil and aquifer layers, and it was also reported to be a source of oxygen for biological treatment of environmental objects $[13,24,25] . \mathrm{H}_{2} \mathrm{O}_{2}$ is used for decontamination (detoxification) of organic pollutants (formaldehyde, phenol, amine, penicillins, surface-active substances (surfactants), herbicides, etc.) $[3,4,18]$.

For the overall assessment of the residual toxicity of the treated water it is necessary to consider the content of $\mathrm{H}_{2} \mathrm{O}_{2}$ since such an assessment is carried out by biological organisms, which are quite sensitive to it and, therefore, should continuously monitor its concentration in the aquatic environment $[8,14,18,28]$.

Probably, $\mathrm{H}_{2} \mathrm{O}_{2}$ is used most widely in medicine and pharmacy as an active ingredient of many antiseptics and disinfectants (the pharmacotherapeutic group: Antiseptics and disinfectants; ATC code D08A X01), such as 3\%, $6 \%$ solutions for external use, Hydroperite, Grillen, Peramine, PEMOS-1, Perkat. Recently, the more advanced forms of these drugs have appeared. For example, there is drug "Peroxygel" (3\% gel) with the bactericidal, mild cauterizing and hemostatic effect. The product contains $\mathrm{H}_{2} \mathrm{O}_{2}$ with the concentration of $3 \%$ as an active substance. In the aqueous medium under the action of catalase it breaks down to water and atomic oxygen. This reaction is accelerated in the presence of traces of hemoglobin of the blood, pus, and necrotic tissues; the foam formed in this reaction loosens the eschar, mechanically cleanses the wound, and after drying and/or removal of the necrotic tissue, pus, etc., a protective film protecting the wound from the secondary infection is formed.

"Peroxygel, 3.0\%" is a colourless or pale white, odourless disperse system. It has the thermoplastic quality: at temperatures below $20^{\circ} \mathrm{C}$ and above $45^{\circ} \mathrm{C}$ it is liquid, but once applied to the skin (i.e. at a temperature of about $36.6^{\circ} \mathrm{C}$ ) it takes the form of a gel. It is contained in a $15 \mathrm{~g}$ aluminium tube with a protective membrane and with a polyethylene bouchon in a cardboard box.

The pharmacopoeian method for determining $\mathrm{H}_{2} \mathrm{O}_{2}$ is the method of permanganometric titration [2]. The extensive literature survey reveals that the most common method of the $\mathrm{H}_{2} \mathrm{O}_{2}$ analysis is spectrophotometry [20, $26,32]$, fluorimetry [16], luminescence [30,34], various types of chromatography $[9,29,31,33]$, electrochemical $[6,7,12,15,27]$ and other methods of analysis $[10,11,32]$.

The most selective, simple and rapid in performance, as well as economically viable electrochemical methods are considered. For example, to determine $\mathrm{H}_{2} \mathrm{O}_{2}$ the direct oxidation on the working electrode (e.g. platinum or carbon) is widely used. Such methods were described in more detail in our review published earlier [1]. However, there are relatively few methods, in which the $\mathrm{H}_{2} \mathrm{O}_{2}$ quantitative determination is performed by reduction on solid electrodes.

Therefore, as can be seen from the above data, development of analytical methods for the $\mathrm{H}_{2} \mathrm{O}_{2}$ quantitative determination is of a great practical importance for various applications, including pharmaceutical analysis. Practical requirements for methods of the $\mathrm{H}_{2} \mathrm{O}_{2}$ concentration determination include such criteria as selectivity, 
high sensitivity and speed of analysis, simplicity, cheapness, and the possibility of their application to standardization of antiseptics and disinfectants.

The aim of the present work is to determine the feasibility of the $\mathrm{H}_{2} \mathrm{O}_{2}$ quantitative determination in a standard pharmacopoeian solution and preparations by cathodic voltammetry using the carbositall rotation electrode $(\mathrm{CE})$ as an indicating electrode.

\section{Materials and Methods}

The standard solution of hydrogen peroxide $\left(\mathrm{H}_{2} \mathrm{O}_{2}\right)$. $0.1700 \mathrm{Mol} \mathrm{L}^{-1}$ was freshly prepared and standardized permanganometrically. The stock solution was prepared by dissolving of $60 \%$ commercial preparation in a $100 \mathrm{~mL}$ volumetric flask by double distilled water. $10.00 \mathrm{~mL}$ of $0.1700 \mathrm{Mol} \mathrm{L}^{-1}$ solution of $\mathrm{H}_{2} \mathrm{O}_{2}$ was diluted in a $1000 \mathrm{~mL}$ volumetric flask with double distilled water to obtain $1.7 \times 10^{-3} \mathrm{Mol} \mathrm{L}^{-1}$ of $\mathrm{H}_{2} \mathrm{O}_{2}$ solution.

The solution of potassium hydrogen sulphate. $1 \mathrm{Mol} \mathrm{L}^{-1}\left(\mathrm{KHSO}_{4}\right)$ was prepared by dissolving of $68.1 \mathrm{~g}$ of $\mathrm{KHSO}_{4}$ in a $500 \mathrm{~mL}$ volumetric flask by double distilled water.

The solution of sodium sulphate. $1 \mathrm{Mol} \mathrm{L}^{-1}\left(\mathrm{NaSO}_{4}\right)$ was prepared by dissolving of $142.0 \mathrm{~g}$ of $\mathrm{NaSO}_{4}$ in a $1000 \mathrm{~mL}$ volumetric flask by double distilled water.

The background solution consisted of the mixture of solutions of potassium hydrogen sulphate $\left(\mathrm{KHSO}_{4}\right)$ and sodium sulphate $\left(\mathrm{Na}_{2} \mathrm{SO}_{4}\right)$.

The sample preparation, which was subjected to the analytical procedures for the analysis of $\mathrm{H}_{2} \mathrm{O}_{2}$, was "Hydrogen peroxide, 3\%" antiseptic ("Farmatsevtychna fabryka", Stanyshivka, Zhytomyr region, Ukraine) and "Peroxygel, 3.0\%" gel ("Hemi" Karczew, Poland).

The model solution of "Hydrogen peroxide, $3 \%$ " antiseptic was prepared by dissolving of $1.0 \mathrm{~mL}$ of the preparation in a $100 \mathrm{~mL}$ volumetric flask by double distilled water to obtain $8.8 \times 10^{-3} \mathrm{Mol} \mathrm{L}^{-1}$ of $\mathrm{H}_{2} \mathrm{O}_{2}$ solution (standardized permanganometrically). $10.00 \mathrm{~mL}$ of this solution was diluted in a $100 \mathrm{~mL}$ volumetric flask with double distilled water to obtain $8.8 \times 10^{-4} \mathrm{Mol} \mathrm{L}^{-1}$ of $\mathrm{H}_{2} \mathrm{O}_{2}$ solution.

The model solution of "Peroxygel, 3.0\%" antiseptic was prepared by dissolving of $1.0 \mathrm{~g}$ of the preparation in a $100 \mathrm{~mL}$ volumetric flask by double distilled water.

The $\mathrm{pH}$ was measured using an ionmeter of I-160M type (Belarus) with a glass electrode of ESL-43-07 type paired with $\mathrm{Ag}, \mathrm{AgCl} / \mathrm{KCl}$ (sat) electrode.

Electrochemical measurements were carried out in an AVS-1.1 analyzer (Volta, St. Petersburg) with a threeelectrode scheme by alternating the current mode with a square wave modulation in the potential range of $+1.0 \ldots-1.0 \mathrm{~V}, \mathrm{~W}=1000 \mathrm{rpm}$, the amplitude of $40 \mathrm{mV}$, $v=65 \mathrm{~Hz}$. The values of potential peaks directly at the maximum were measured by the electrochemical sensor "Module EM-04" with the accuracy of $\pm 5 \mathrm{mV}$. CE was used as a working and an auxiliary electrode, and $\mathrm{Ag}, \mathrm{AgCl} / \mathrm{KCl}$ (sat) electrode type $\mathrm{EVL}-1 \mathrm{M} 4$ as a reference electrode.

The procedure for obtaining results of the calibration graph. The working solutions were prepared by diluting different volumes of the stock solution $(0.5-3.0 \mathrm{~mL})$ in a $50 \mathrm{~mL}$ volumetric flask with the background solution. $25 \mathrm{~mL}$ of the working solution was transferred to the cell. The voltammograms were recorded by scanning the potential toward the negative direction in the potential range from $+1.0 \mathrm{~V}$ to $-1.0 \mathrm{~V}$ (vs Ag, $\mathrm{AgCl} / \mathrm{KCl}(\mathrm{sat})$ ). The graph was plotted in the following coordinates: the height of peaks $I_{\mathrm{p}}$ in $\mu \mathrm{A}$ at $E_{\mathrm{p}}=+0.16 \mathrm{~V}$ on the ordinate axis and the corresponding concentration of $\mathrm{H}_{2} \mathrm{O}_{2}, c$ in $\mathrm{Mol} \mathrm{L}^{-1}$ on the abscissa axis (Fig. 3). The graph equation coefficients were calculated by the least square method.

The working solutions were prepared by diluting different volumes $(1.00-2.00 \mathrm{~mL})$ of the test solution $\left(\approx 1 \times 10^{-3} \mathrm{Mol} \mathrm{L}^{-1}\right)$ with $2.00 \mathrm{~mL}$ of the stock solution of $\mathrm{H}_{2} \mathrm{O}_{2}\left(1.7 \times 10^{-3} \mathrm{Mol} \mathrm{L}^{-1}\right)$ in a $50 \mathrm{~mL}$ volumetric flask with the background solution. The voltammograms were recorded by scanning the potential toward the negative direction in the potential range from $+1.0 \mathrm{~V}$ to $-1.0 \mathrm{~V}$ (vs $\mathrm{Ag}, \mathrm{AgCl} / \mathrm{KCl}(\mathrm{sat})$ ). The concentration of the test solution $C_{\mathrm{x}}\left(\mathrm{Mol} \mathrm{L}^{-1}\right)$ is calculated by the equation:

$$
C_{\mathrm{x}}=\frac{I_{\mathrm{n}}-b}{a},
$$

where: $I_{\mathrm{x}}-$ is the current peak of the test solution; $a$, $b-$ are graph equation coefficients.

It was found that the surface active substances (SAS) being a part of the test solution of the sample preparation had the catalytic effect (current increase). Therefore, it was decided to use the addition method for analysis of the preparation.

The procedure of the quantitative determination of $\mathrm{H}_{2} \mathrm{O}_{2}$ in "Hydrogen peroxide, $3 \%$ " antiseptic. A typical procedure involves preparing several solutions containing the same amount of the unknown solution, but different amounts of the standard solution. For example, three $50 \mathrm{~mL}$ volumetric flasks are filled with $1.00 \mathrm{~mL}$ of the unknown solution each, and then the standard solution is added in different amounts, such as from 0.50 to $2.00 \mathrm{~mL}$. The flasks are then diluted to the volume and mixed well. $25 \mathrm{~mL}$ of each solution prepared are transferred to the cell. The voltammograms are recorded by scanning the potential toward the negative direction in the potential range from $+1.0 \mathrm{~V}$ to $-1.0 \mathrm{~V}$.

At first, the voltammogram of test solution is recorded, then the solution of the known aliquots of the standard solution of $C_{\mathrm{st}}\left(\mathrm{Mol} \mathrm{L}^{-1}\right)$ is added, and again the voltammogram is recorded. The concentration of the test solution $C_{\mathrm{x}}\left(\mathrm{Mol} \mathrm{L}^{-1}\right)$ is calculated by the equation:

$$
C_{\mathrm{x}}=C_{\mathrm{st}} \cdot \frac{I_{\mathrm{x}}}{I_{\mathrm{x}+\mathrm{st}}-I_{\mathrm{x}}},
$$

where: $I_{\mathrm{x}}-$ is the current peak of the test solution; $I_{\mathrm{x}+\mathrm{st}}-$ is the current peak of the test solution with addition of a standard substance.

The mass fraction of $\mathrm{H}_{2} \mathrm{O}_{2}(w, \%)$ in the test solution is calculated by the equation:

$$
w, \%=\frac{C_{\mathrm{x}} \cdot 34.01 \cdot 100 \cdot 100 \cdot V_{0}}{m \cdot 1000 \cdot 10 \cdot V} \cdot 100 \%,
$$

where: 34.01 - is the molar weight of $\mathrm{H}_{2} \mathrm{O}_{2}, \mathrm{~g} \mathrm{Mol}^{-1}$; $V_{0}$ - is the volumetric flask capacity; $V-$ is the volume 


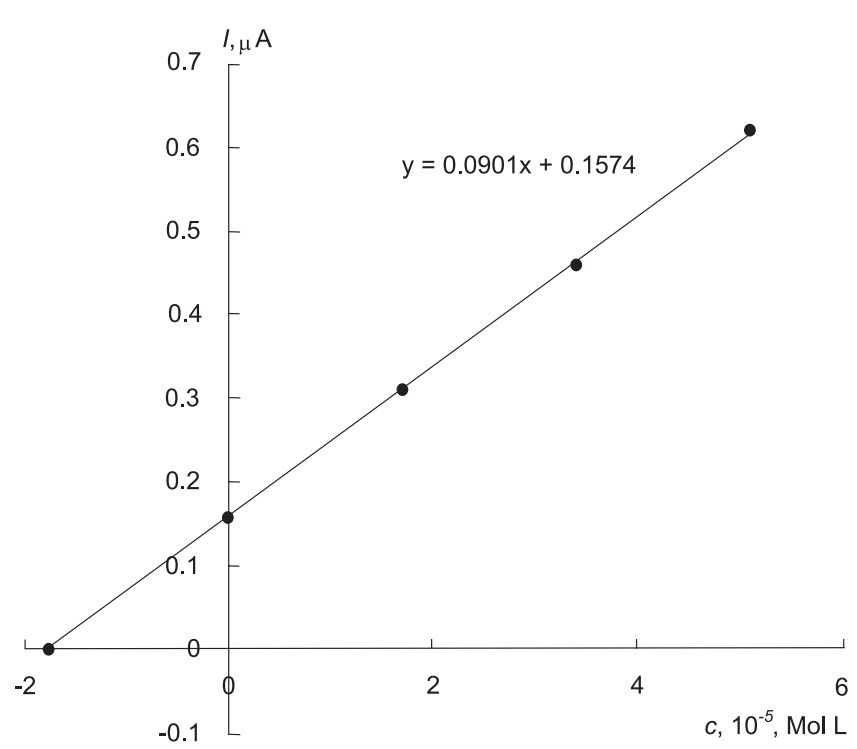

Fig. 1. The graph of the $\mathrm{H}_{2} \mathrm{O}_{2}$ reduction current peak vs. the concentration on the background of $0.1 \mathrm{Mol} \mathrm{L}^{-1} \mathrm{Na}_{2} \mathrm{SO}$ and $0.01 \mathrm{Mol} \mathrm{L}^{-1} \mathrm{KHSO}_{4}(\mathrm{pH} \approx 2.4)$ on $\mathrm{CE}$ (vs Ag, $\mathrm{AgCl} / \mathrm{KCl}($ sat)); $E_{p}=+0.16 \mathrm{~V}$

of the test solution; $m$ - is the sample weight, $\mathrm{g} ; 10-$ is the volume of the stock solution; 100, 1000 - are volumetric flask capacities.

The procedure of the quantitative determination of $\mathrm{H}_{2} \mathrm{O}_{2}$ in "Peroxygel, 3.0\%" gel. The working solutions are prepared by diluting different volumes $(0.5-1.5 \mathrm{~mL})$ of the stock solution with the same amount of the test solution of $\mathrm{H}_{2} \mathrm{O}_{2}\left(1.7 \times 10^{-3} \mathrm{Mol} \mathrm{L}^{-1}\right)$ in a $50 \mathrm{~mL}$ volumetric flask with the background solution. The voltammograms are recorded by scanning the potential toward the negative direction in the potential range from $+1.0 \mathrm{~V}$ to $-1.0 \mathrm{~V}$ (vs $\mathrm{Ag}, \mathrm{AgCl} / \mathrm{KCl}(\mathrm{sat})$ ). The graph is plotted in the following coordinates: the height of peaks $I_{\mathrm{p}}$ in $\mu \mathrm{A}$ at $E_{\mathrm{p}}=+0.16 \mathrm{~V}$ on the ordinate axis and the corresponding concentration of $\mathrm{H}_{2} \mathrm{O}_{2} c$ in $\mathrm{Mol} \mathrm{L}-1$ on the abscissa axis (Fig. 1).

The mass fraction of $\mathrm{H}_{2} \mathrm{O}_{2}(\%)$ in the test solution is calculated by the equation:

$$
X, \%=\frac{C_{\mathrm{x}} \cdot 34.01 \cdot 100 \cdot V_{0}}{m \cdot 1000 \cdot \mathrm{V}} \cdot 100 \%,
$$

where: 34.01 - is the molar weight of $\mathrm{H}_{2} \mathrm{O}_{2}, \mathrm{~g} \mathrm{Mol}^{-1}$; $V_{0}$ - is the volumetric flask capacity; $V-$ is the volume

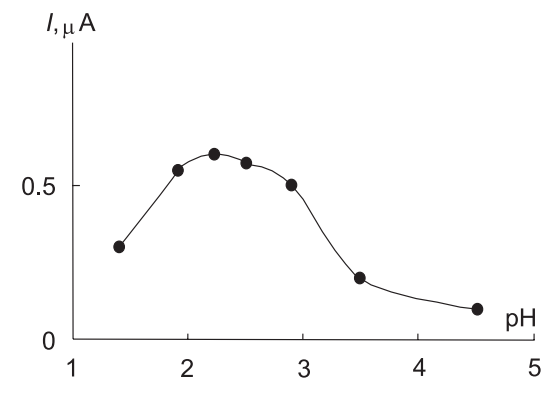

of the test solution; $m$ - is the sample weight, $\mathrm{g} ; C_{x}-$ is the graph of the $\mathrm{H}_{2} \mathrm{O}_{2}$ (regression line equation) found concentration, Mol L ${ }^{-1}: y=a x+b$ where $a, b-$ are the graph equation coefficients; $y-I_{\mathrm{p}}(\mu \mathrm{A})$.

When $y=0 ; C_{x}=x=-b / a$.

\section{Results and Discussion}

The effect of the nature and pH of the background solution. The effect of the $\mathrm{pH}$ on the reduction process was studied by recording voltammograms of $\mathrm{H}_{2} \mathrm{O}_{2}$ in the concentration of $6.8 \times 10^{-5} \mathrm{Mol} \mathrm{L}^{-1}$ at several $\mathrm{pH}$ values ranging from 1.4 to 4.5 (Fig. 2). The mixture of $0.1 \mathrm{Mol} \mathrm{L}^{-1} \mathrm{Na}_{2} \mathrm{SO}_{4}+0.01 \mathrm{Mol} \mathrm{L}^{-1} \mathrm{KHSO}_{4}$ was used as a background solution, and the $\mathrm{pH}$ of the solution was changed when gradually adding $\mathrm{NaOH} 0.2 \mathrm{Mol} \mathrm{L}^{-1}$.

As can be seen from the graph (Fig. 2), the height of the $\mathrm{H}_{2} \mathrm{O}_{2}$ reduction peak decreases, and the potential of the reduction peak is shifted toward more electronegative values with increasing the background electrolyte $\mathrm{pH}$ from 1.4 to 4.5 . The maximum peak $\left(I_{\mathrm{p}}\right)$ is at the $\mathrm{pH}$ of approximately 2.2 and at a the $\mathrm{pH}$ around 4 the analytical signal almost disappears. The effect of the $\mathrm{pH}$ on the peak potential $\left(E_{\mathrm{p}}\right)$ shows the following: when the $\mathrm{pH}$ value increases in the interval from 2 to $3, E_{\mathrm{p}}$ remains almost constant, but $E_{\mathrm{p}}$ decreases sharply to a negative value with the $\mathrm{pH}$ increasing over 3.5. Therefore, the optimal peak for the analysis $\left(E_{\mathrm{p}}=+0.16 \mathrm{~V}\right)$ was obtained at $\mathrm{pH} \approx 2.2-2.4$ on the background of $\mathrm{Na}_{2} \mathrm{SO}_{4}$ and $\mathrm{Mol} \mathrm{L}^{-1} \mathrm{KHSO}_{4}$.

For the quantitative determination of $\mathrm{H}_{2} \mathrm{O}_{2}$ in a standard pharmacopoeian solution the calibration curve method was used. The calibration curve equation was $I_{\mathrm{p}}=(8.6 \pm 0.7) \times$ $10^{3} \times_{C}(\mathrm{r}=0.998)$ (Fig. 3). The results obtained are summarized in Tab. 1.

The high sensitivity of this method is accompanied by very good reproducibility. The reproducibility was evaluated from 5 repeated electrochemical signal measurements of model solutions with $\mathrm{H}_{2} \mathrm{O}_{2}$ concentrations of $5.10 \times 10^{-5}, 6.80 \times 10^{-5}$ and $8.50 \times 10^{-5} \mathrm{Mol} \mathrm{L}^{-1}$. Precision of the method developed with reference to the relative standard deviation (RSD) was 4.24\%, 3.27\% and 2.30\%, respectively $(n=5, P=0.95)$. The results obtained are summarized in Tab. 2.

Precision and accuracy of the voltammetric determination of $\mathrm{H}_{2} \mathrm{O}_{2}$ in the model solution of preparations were studied by analyzing five replicates of the sample

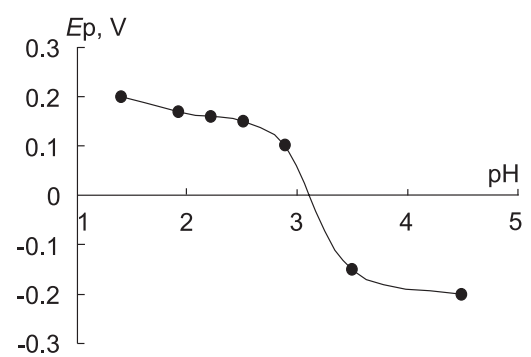

b

Fig. 2. The effect of the $\mathrm{pH}$ on the current peak intensity $(a)$ and the peak potential $(b)$ of the reduction process of $\mathrm{H}_{2} \mathrm{O}_{2}$ on $\mathrm{CE}$ (vs Ag, AgCl/KCl(sat)). 


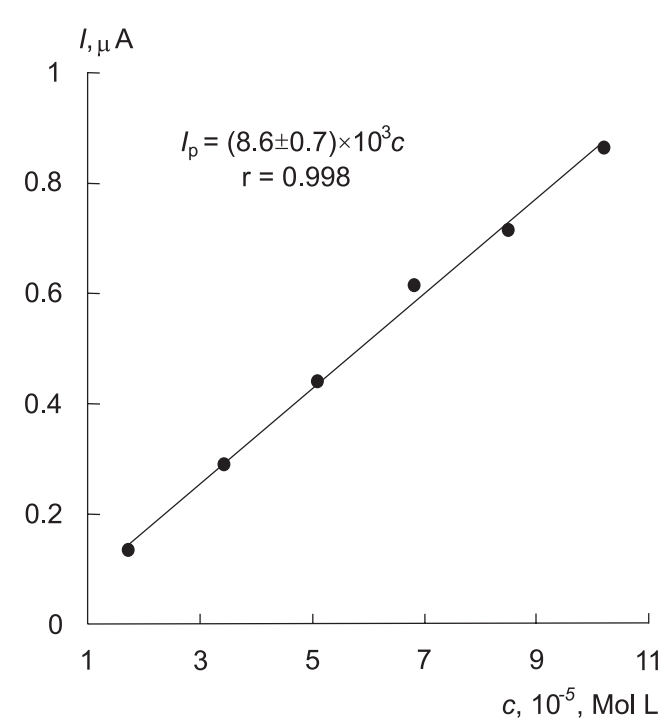

Fig. 3. The calibration graph of the $\mathrm{H}_{2} \mathrm{O}_{2}$ reduction current peak vs. the concentration on the background of $0.1 \mathrm{Mol} \mathrm{L}^{-1} \mathrm{Na}_{2} \mathrm{SO}_{4}$ and $0.01 \mathrm{Mol} \mathrm{L}^{-1} \mathrm{KHSO}_{4}(\mathrm{pH} \approx 2.4)$ on $\mathrm{CE}$ (vs Ag, $\mathrm{AgCl} / \mathrm{KCl}(\mathrm{sat})$ ); $\mathrm{E}_{\mathrm{p}}=+0.16 \mathrm{~V}$

Table 1

Analytical characteristics of the calibration graph of the $\mathrm{H}_{2} \mathrm{O}_{2}$ voltammetric determination procedure in a standard pharmacopoeian solution $(\mathrm{y}=a \mathrm{x}+b)$

\begin{tabular}{|l|c|}
\hline \multicolumn{1}{|c|}{ Parameters } & Data \\
\hline Concentration ranges $\left(\mathrm{Mol} \mathrm{L}^{-1}\right)$ & $(1.7-10.2) \times 10^{-5}$ \\
\hline Regression equation & $I_{\mathrm{n}}=(8.6 \pm 0.7) \times 10^{3} \mathrm{C}$ \\
\hline a & $8.6 \times 10^{3}$ \\
\hline $\mathrm{b}$ & 0.011 \\
\hline$\Delta a$ & $0.7 \times 10^{3}$ \\
\hline$\Delta b$ & 0.05 \\
\hline $\mathrm{S}_{\mathrm{a}}$ & $0.3 \times 10^{3}$ \\
\hline $\mathrm{S}_{\mathrm{b}}$ & 0.02 \\
\hline Correlation coefficient $(r)$ & 0.998 \\
\hline LOD (Mol L $\left.{ }^{-1}\right)$ & $6.16 \times 10^{-6}$ \\
\hline LOQ (Mol L-1) & $2.05 \times 10^{-5}$ \\
\hline
\end{tabular}

Table 2

The assessment of accuracy and precision of the $\mathrm{H}_{2} \mathrm{O}_{2}$ voltammetric determination procedure in the model solution of the standard pharmacopoeian solution $(n=5 ; \mathrm{P}=0.95 \%)$

\begin{tabular}{|c|c|c|c|c|c|}
\hline Taken $\left(\mathrm{Mol} \mathrm{L}^{-1}\right)$ & Found $\left(\mathrm{Mol} \mathrm{L}^{-1}\right)$ & Reproducibility $(\% \pm \mathrm{SD})$ & $\mathrm{RSD}(\%)$ & $\varepsilon(\%)$ & $\delta^{*}(\%)$ \\
\hline $5.10 \times 10^{-5}$ & $(5.13 \pm 0.27) \times 10^{-5}$ & $100.64 \pm 5.31$ & 4.24 & 5.27 & +0.60 \\
\hline $6.80 \times 10^{-5}$ & $(6.86 \pm 0.28) \times 10^{-5}$ & $100.88 \pm 4.10$ & 3.27 & 4.06 & +0.90 \\
\hline $8.50 \times 10^{-5}$ & $(8.51 \pm 0.24) \times 10^{-5}$ & $100.06 \pm 2.86$ & 2.30 & 2.85 & +0.05 \\
\hline
\end{tabular}

Note: * In relation to the average reference method of permanganatometric titration [2].

Table 3

The results of voltammetric determination of $\mathrm{H}_{2} \mathrm{O}_{2}$ in the model solution of preparations $(n=5 ; P=0.95 \%)$

\begin{tabular}{|c|c|c|c|c|c|c|}
\hline \multicolumn{1}{|c|}{ Object } & Taken*(\%) & Found (\%) & $\begin{array}{c}\text { Reproducibility } \\
(\% \pm S D)\end{array}$ & RSD (\%) & $\varepsilon(\%)$ & $\delta^{*}(\%)$ \\
\hline "Hydrogen peroxide, 3.0\%" & $3.08 \pm 0.19$ & $3.03 \pm 0.08$ & $98.44 \pm 2.59$ & 2.11 & 2.63 & -1.56 \\
\hline "Peroxygel, 3.0\%" & $3.00 \pm 0.30$ & $2.98 \pm 0.09$ & $99.33 \pm 3.03$ & 2.45 & 2.63 & -0.67 \\
\hline
\end{tabular}

Note: * The calculation was made according to the average content determined by the pharmacopeian procedure.

solutions at three concentration levels. The results obtained are summarized in Tab. 3.

CONCLUSIONS

Thus, a new voltammetric method of the $\mathrm{H}_{2} \mathrm{O}_{2}$ determination in a standard pharmacopoeian solution and the model solution of preparations, such as antiseptics "Hydrogen peroxide, 3.0\%" and "Peroxygel, 3.0\%" using CE as an indicating electrode has been developed, and the possibility of its quantitative determination has been shown.
The linear dependence is observed in the concentration ranges of the pure substance from $1.70 \times 10^{-5}$ to $10.20 \times 10^{-5} \mathrm{Mol} \mathrm{L}^{-1}$. The calibration curve equation is $I_{\mathrm{p}}=(8.6 \pm 0.7) \times 10^{3} \times \mathrm{c}(\mathrm{r}=0.998) ; \mathrm{LOD}=6.16 \times 10^{-6} \mathrm{Mol} \mathrm{L}^{-1}$, $\mathrm{LOQ}=2.05 \times 10^{-5} \mathrm{Mol} \mathrm{L}^{-1}$. To determine $\mathrm{H}_{2} \mathrm{O}_{2}$ in preparations the standard addition method was used. The RSD was $2.11 \%(\delta=-1.56 \%)$ for "Hydrogen peroxide, $3.0 \%$ " and $2.45 \%(\delta=-0.67 \%)$ for "Peroxygel, $3.0 \%$ ", respectively.

\section{REFERENCES}

1. Блажеєвський М.С., Мозгова О.О. // Пробл. екол. мед. генет. клін. імунол. - 2014. - Вип. 4 (124). - С. $70-86$.

2. Державна фармакопея України / Державне підприємство «Науково-експертний фармакопейний ияентр». 1-е вид. - Доп. 1. - 2009. - С. 310.

3. Левковеи И.А., Стародуб Н.Ф. // Хим. технол. воды - 2003. - T. 25, №1. - С. 30-42.

4. Benitez F.J. // Chemosph. - 2000. - Vol. 41, №8. - P. 1271-1277. 
5. Blazheyevskiy N., Riabko D. // Gisap: Med. Sci., Pharmacol. - 2016. - №9. - P. 33-38.

6. Campanella L. // J. Pharm. Biomed. Anal. - 2003. - Vol. 32, №4. - P. 737-751.

7. Campanella L., Roversi R., Sammartino M.P., Tomassetti M. // J. Pharm. Biom. Anal. - 1998. - Vol. 18. - P. 105-116.

8. Deng Y., Zuo Y. // Atmosph. Environ. - 1999. - Vol. 33, №9. - P. 1469-1478.

9. Effkemann S., Pinkernell U., Karst U. // Anal. Chim. Acta. - 1998. - Vol. 363. - P. 97-10.

10. Harms D., Karst U. //Analytica Chimica Acta. - 1999. - Vol. 389, №1. - P. 233-238.

11. Higashi N., Yokota H., Hiraki S., Ozaki Y. / Anal. Chem. - 2005. - Vol. 77, №. 7. - P. 2272-2277.

12. Kicela A., Daniele S. // Talanta. - 2006. - Vol. 68. - P. 1632-1639.

13. Kleiser G., Frimmel F. H. //Sci. Tot. Environ. - 2000. - Vol. 256, № 1. - P. 1-9.

14. Lee J. H., Tang I. N., Weinstein-Lloyd J. B. // Anal. Chem. - 1990. - Vol. 62, № 21. - P. 2381-2384.

15. Ojania R., Raoof J. B., Babazadeh R. // J. Chin. Chem. Soc. - 2010. - Vol. 57, № 5A. - P. 1042-1049.

16. Paital B. A // BioMed Res. Int. - 2014. - Vol. 2014. - 8 p. Режним достуny: http://dx.doi.org/10.1155/2014/342958.64

17. Pardieck D. L., Bouwer E. J., Stone A. T. // J. Contam. Hydrol. - 1992. - Vol. 9, № 3. - P. 221-242.

18. Peña R. M. // Atmosph. Environ. - 2001. - Vol. 35, № 2. - P. 209-219.

19. Petri B. G. // In Situ Chem. Oxid. Groundwater Remed. - Springer New York, 2011. - P. 33-88.

20. Pettas I. A., Karayannis M. I. // Anal. Chim. Acta. - 2004. - Vol. 522, №. 2. - P. 275-280.

21. Pokhrel D., Viraraghavan T. // Sci. Tot. Envir. - 2004. - Vol. 333, № 1. - P. 37-58.

22. Saaymant G. B., Schutte C. F., Leeuwen J. //Water Sci. Technol. - 1996. - Vol. 34. - P. 275-282.

23. Schumb, W. C., Satterfield, C. N., Wentworth, R. L. // ACS Monograph Series. - 1955. - 459 p.

24. Stemmler K., Gunten U. // Atmosph. Environ. - 2000. - Vol. 34, № 25. - P. 4241-4252.

25. Stemmler K., Gunten U. // Atmosph. Environ. - 2000. - Vol. 34, № 25. - P. 4253-4264.

26. Sunil K., Narayana B. // Bull. Envir. Cont. Toxicol. - 2008. - Vol. 81, №. 4. - P. 422-426.

27. Sužnjević D. // Electroanal. - 1997. - Vol. 9, № 11. - P. 861-864.

28. Taniai T., Sakuragawa A., Okutani T. // Anal. Sci. - 2000. - Vol. 16, № 3. - P. 275-282.

29. Tarvina M., McCord B., Mount K. // J. Chromatogr. A. - 2010. - Vol. 1217. - P. 7564-7572.

30. Tsaplev Y. B. // J. Anal. Chem. - 2012. - Vol. 67, № 6. - P. 506-514.

31. Wasylaschuk W. R. // J. Pharm. Sci. - 2007. - Vol. 96, №. 1. - P. 106-116.

32. Woo Y. A. // J. Pharm. Biomed. Analysis. - 2003. - Vol. 33, №. 5. - P. 1049-1057.

33. Yue H. //Intern. J. Pharm. - 2009. - Vol. 375, №. 1. - P. 33-40.

34. Zhou Y. // Talanta. - 1999. - Vol. 48, № 2. - P. 461-467.

\section{КІЛЬКІСНЕ ВИЗНАЧЕННЯ ГІДРОГЕНУ ПЕРОКСИДУ МЕТОДОМ ВОЛЬТАМПЕРОМЕТРІЇ НА ВУГЛЕСИТАЛОВОМУ ЕЛЕКТРОДІ \\ М.Є.Блажеєвський, О.О.Мозгова}

Ключові слова: визначення; гідрогену пероксид; вольтамперометрія; карбоситаловий електрод; антисептичний засіб

Методом катодної вольтамперометрії з використанням як індикаторного вуглеситалового электроду вивчена електрохімічна поведінка гідрогену пероксиду в інтервалі потенціалів $E=+1,0 \ldots-1,0$ B (відн. нас. Ag,AgCl/KCl). Пік (In) був отриманий при $E_{n}=+0,16$ В на фроні 0, 1 Моль/л $\mathrm{Na}_{2} \mathrm{SO}_{4}$ та 0,01 Моль/л $\mathrm{KHSO}_{4}(\mathrm{pH} \approx 2,4)$, висота якого зростає зі збільшенням концентрації $\mathrm{H}_{2} \mathrm{O}_{2}$. Лінійна залежність спостерігалася в інтервалі концентрацій (1.70-10.20)·10-5 Моль/л, рівняння градуювального графріка має вигляд: $I_{n}=(8,6 \pm 0,7) \cdot 10^{3} \mathrm{C}(r=0,998) ; L O D=6,16 \cdot 10^{-6}$ Моль/л, $L O Q=$ $2,05 \cdot 10^{-5}$ Моль/л. Для визначення $\mathrm{H}_{2} \mathrm{O}_{2}$ у розчинах антисептичних препаратів використовували метод добавок.

\section{КОЛИЧЕСТВЕННОЕ ОПРЕДЕЛЕНИЕ ПЕРОКСИДА ВОДОРОДА МЕТОДОМ ВОЛЬТАМПЕРОМЕРИИ НА УГЛЕСИТАЛЛОВОМ ЭЛЕКТРОДЕ \\ Н.Е.Блажеевский, Е.А.Мозговая}

Ключевые слова: определение; пероксид водорода; вольтамперометрия; углеситалловый электрод; антисептическое средство

Методом катодной вольтамперометрии с использованием в качестве индикаторного углеситаллового электрода изучено электрохимическое поведение пероксида водорода в интервале потенциалов $E=+1,0 \ldots-1,0$ B (отн. нас. $\mathrm{Ag}, \mathrm{AgCl} / \mathrm{KCl})$. Пик (In) был получен при $E_{n}=+0,16$ В на фроне 0,1 Моль/л $\mathrm{Na}_{2} \mathrm{SO}_{4}$ и 0,01 Моль/л $\mathrm{KHSO}_{4}(\mathrm{pH} \approx 2,4)$, высота которого увеличивается с ростом концентрации $\mathrm{H}_{2} \mathrm{O}_{2}$. Линейная зависимость наблюдалась в диапазоне концентраций (1.70-10.20)·10-5 Моль/л, уравнение калибровочного графрика: $I_{n}=(8,6 \pm 0,7) \cdot 10^{3} \mathrm{C}$ $(r=0,998) ; L O D=6,16 \cdot 10^{-6}$ Моль/л, $L O Q=2,05 \cdot 10^{-5}$ Моль/л. Для определения $\mathrm{H}_{2} \mathrm{O}_{2}$ в растворах антисептических препаратов использовали метод добавок. 